\title{
Integrated Geophysical Investigations to Detect the Shallow Subsurface Settings at New Sohag City, Egypt
}

\author{
Hany Mesbah', Mohammed Shokry², Mamdouh Soliman'1, Magdy Atya1 \\ ${ }^{1}$ National Research Institute of Astronomy and Geophysics (NRIAG), Helwan, Cairo, Egypt \\ ${ }^{2}$ Geophysics Department, Faculty of Science, Ain Shams University, Cairo, Egypt \\ Email: hmesbah2000@yahoo.com
}

How to cite this paper: Mesbah, H., Shokry, M., Soliman, M. and Atya, M. (2017) Integrated Geophysical Investigations to Detect the Shallow Subsurface Settings at New Sohag City, Egypt. International Journal of Geosciences, 8, 364-377.

https://doi.org/10.4236/ijg.2017.83019

Received: January 28, 2017

Accepted: March 28, 2017

Published: March 31, 2017

Copyright $\odot 2017$ by authors and Scientific Research Publishing Inc. This work is licensed under the Creative Commons Attribution International License (CC BY 4.0). http://creativecommons.org/licenses/by/4.0/

\begin{abstract}
New Sohag City has an area of approximately 1300 acres (546 hectares) and is located within Sohag Governorate limits, about $18 \mathrm{~km}$ away from old Sohag City. It is established to reduce the population within the old Sohag city and to create better economic conditions in a new appropriate living environment. The main target of this study is to apply the relevant surface geophysical methods to image the shallow subsurface setting, to define the shallow lithological layers and to locate any geological structures that may be cause cracks in buildings, and any unstable materials, which may decrease the bearing capacity or human activities, hence increasing hazards in the study area. This study embraces, Electrical Resistivity Tomography (ERT), Shallow Seismic Refraction (SSR), and Ground Penetrating Radar surveys (GPR). The integrated interpretation of all techniques classified the subsurface layers into two layers. A strong reflector separating the upper gravel and calcareous sandy layer from the lower clayey layer. They gave also interesting information about the geotechnical competent of the ground and some structural features in the study area.
\end{abstract}

\section{Keywords}

Electrical Resistivity Tomography, Shallow Seismic Refraction, Ground Penetrating Radar, New Sohag City

\section{Introduction}

Sohag Governorate is located at $467 \mathrm{~km}$ south of Cairo. The Red-Sea and New Valley Governorates are the eastern and western boundaries of Sohag Governorate, respectively. Old Sohag city occupies a region including both the floodplain 
and the desert fringes between latitudes $26^{\circ} 00^{\prime} \mathrm{N}$ and $27^{\circ} 00^{\prime} \mathrm{N}$ and longitudes $31^{\circ} 15^{\prime} \mathrm{E}$ and $32^{\circ} 15^{\prime} \mathrm{E}$. The Nile flood plain soil extended along the two banks of the River Nile for about $10 \mathrm{~km}$. contrarily, it constitutes only a very narrow strip along the eastern side. Figure 1 shows the location map of New Sohag City.

New Sohag City (Akhmim Center) utilized three geophysical surveys: Electrical Resistivity Tomography "ERT", Shallow Seismic Refraction "SSR", and Ground Penetrating Radar "GPR" to delineate any structural features, and characterize of the nature of the foundation materials.

\section{Geological Setting}

\subsection{Surface Geology}

Geologically, many authors have studied the area (e.g. [13] [14] [19] [20] [21] [27] [28] [29] [30] [33] [34]). The area under consideration represents a part of the Nile valley zone of Egypt. Figure 2 is the geologic map of Sohag Governorate

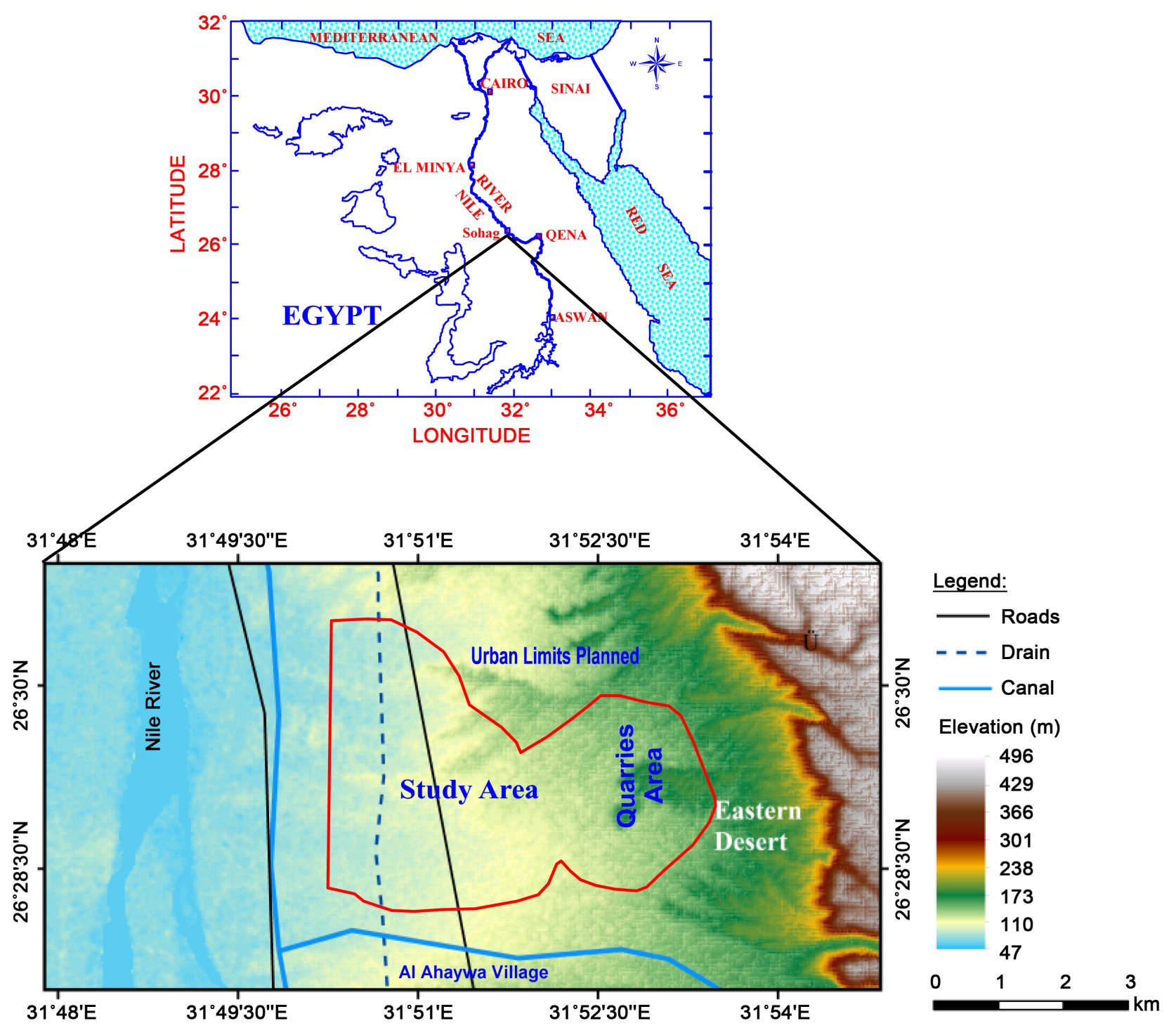

Figure 1. Location map of new Sohag city. 


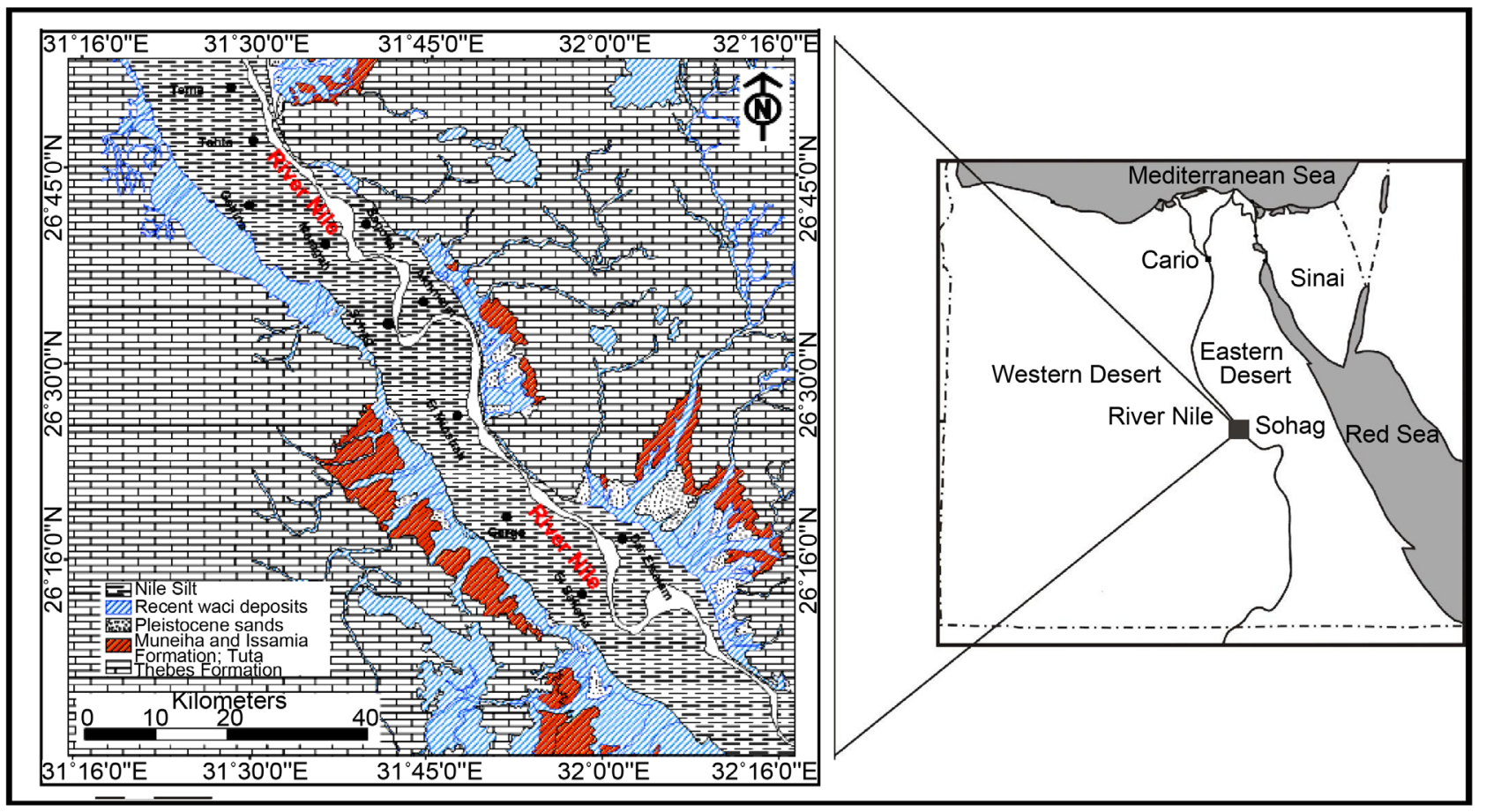

Figure 2. Geological map of Sohag Governorate [6].

including the study area [6].

\subsection{Stratigraphy}

Paleogene sediments and narrow cultivated stretch bordering the Nile River cover most of the area under investigation. This cultivated land has been formed through the flood season of the river Nile since a long time to form the Nile sediments (Pleistocene and Recent deposits).

Several attempts have been done by several authors to discuss the stratigraphy of the Nile Valley, such as (e.g. [1] [2] [7] [10] [11] [12] [17] [18] [23] [24] [25] [26] [30] [32]. The Paleogene rock units in the Nile basin classified into Dakhla Shale and Esna Shale at the base (Paleogene age) followed on the top by Thebes Group, Minia Formation, Mokattam Group and Maadi Group (Eocene) [23] [25] [30]. The Paleogene sediments based on their faunal contentsclassified into the Esna shale at the base overlain by the Assiuti Chalk and the Manfalut Formation at the top; both are the time equivalent of Said's Thebes Formation [1] [2]. Nine distinctive formations in the Late Early Cretaceous-Early Paleogene succession in the Nile Valleyrecognized by [7].

The stratigraphic section of new Sohag city, Akmim center has been studied and described as shown in Figure 3 [8].

\section{Data Acquisition}

\subsection{Electrical Resistivity Tomography (ERT)}

The utmost constraint of the resistivity sounding method is that it does not take into consideration the horizontal changes in the subsurface resistivity. The ERT 


\begin{tabular}{|c|c|c|c|c|c|c|c|}
\hline $\begin{array}{c}\text { Depth } \\
\text { (m) }\end{array}$ & $\begin{array}{c}\text { Thickness } \\
\text { (m) }\end{array}$ & Texture & $\begin{array}{l}\text { Sedimentary } \\
\text { Facies }\end{array}$ & $\begin{array}{c}\text { Depositional } \\
\text { Environment }\end{array}$ & Lithology & Age & $\begin{array}{l}\text { Elev. } \\
(\mathrm{m})\end{array}$ \\
\hline $\begin{array}{l}25- \\
50 \\
75 \\
100- \\
125 \\
150\end{array}$ & $\begin{array}{c}50-250 \\
\text { Average } \\
150\end{array}$ & Fine & Candy & Fluvial & $\begin{array}{l}\text { Sand and } \\
\text { gravel with } \\
\text { clay lenses }\end{array}$ & 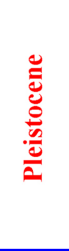 & \begin{tabular}{|l}
-50 \\
-25 \\
-0 \\
-25 \\
--50 \\
-75 \\
\end{tabular} \\
\hline $\begin{array}{l}175- \\
200- \\
225- \\
250- \\
275- \\
300- \\
325- \\
350- \\
375-\end{array}$ & $>225$ & Fine & Clayey & Marine & Clay & 苂 & $\begin{array}{l}-100 \\
--125 \\
-150 \\
-175 \\
-200 \\
-225 \\
-250 \\
-275 \\
-300\end{array}$ \\
\hline
\end{tabular}

Figure 3. Typical lithological section of Akhmim center [8].

survey conquers this problem, where the resistivity changes in the horizontal direction as well as in the vertical direction along the survey line. Therefore, ERT technique selected for this survey. While, the Wenner array gives the smallest number of possible measurements compared to the other common arrays [9], also it competent to work in noisy fields and when good vertical resolution is required. The Wenner array was used in the present work.

The geo-electrical data is collected along thirteen parallel (ERT) profiles using the Wenner electrode arrangement with maximum spread of $160 \mathrm{~m}, 5 \mathrm{~m}$ spacing between the electrodes and $10 \mathrm{~m}$ interline distance using the SYSCAL R2 system. Through the ERT survey, the penetrated depth reaches about $20 \mathrm{~m}$. A built-in microcomputer together with an electronic switching unit is used to automatically select the relevant four electrodes for each measurement as shown in Figure 4.

\subsection{Shallow Seismic Refraction Survey (SSR)}

Seismic exploration involves generation of seismic waves and recording the arrival times of these waves from the source to the series of geophones [4]. Seismic refraction is used to evaluate the necessary parameters for constructions, or to solve the problems related to the geologic nature of sub-surfaces, mining works, and the environmental conditions overcame in the site [5] [31].

Twenty-six seismic refracted profiles (forward and reverse shots) acquired using an exploration seismograph model "DOLANG-Italy". Thirteen profiles for (P-wave) and thirteen profiles for (SH-wave) conducted parallel to the north direction of the study area as shown in Figure 4. The length of all profiles is about 75 meters, where the geophone interval is 6 meters and the shot points are 4.5 meters far from the first and the last geophones.

\subsection{Ground Penetrating Radar (GPR)}

Ground penetrating radar (GPR) is a high-frequency electromagnetic technique; 


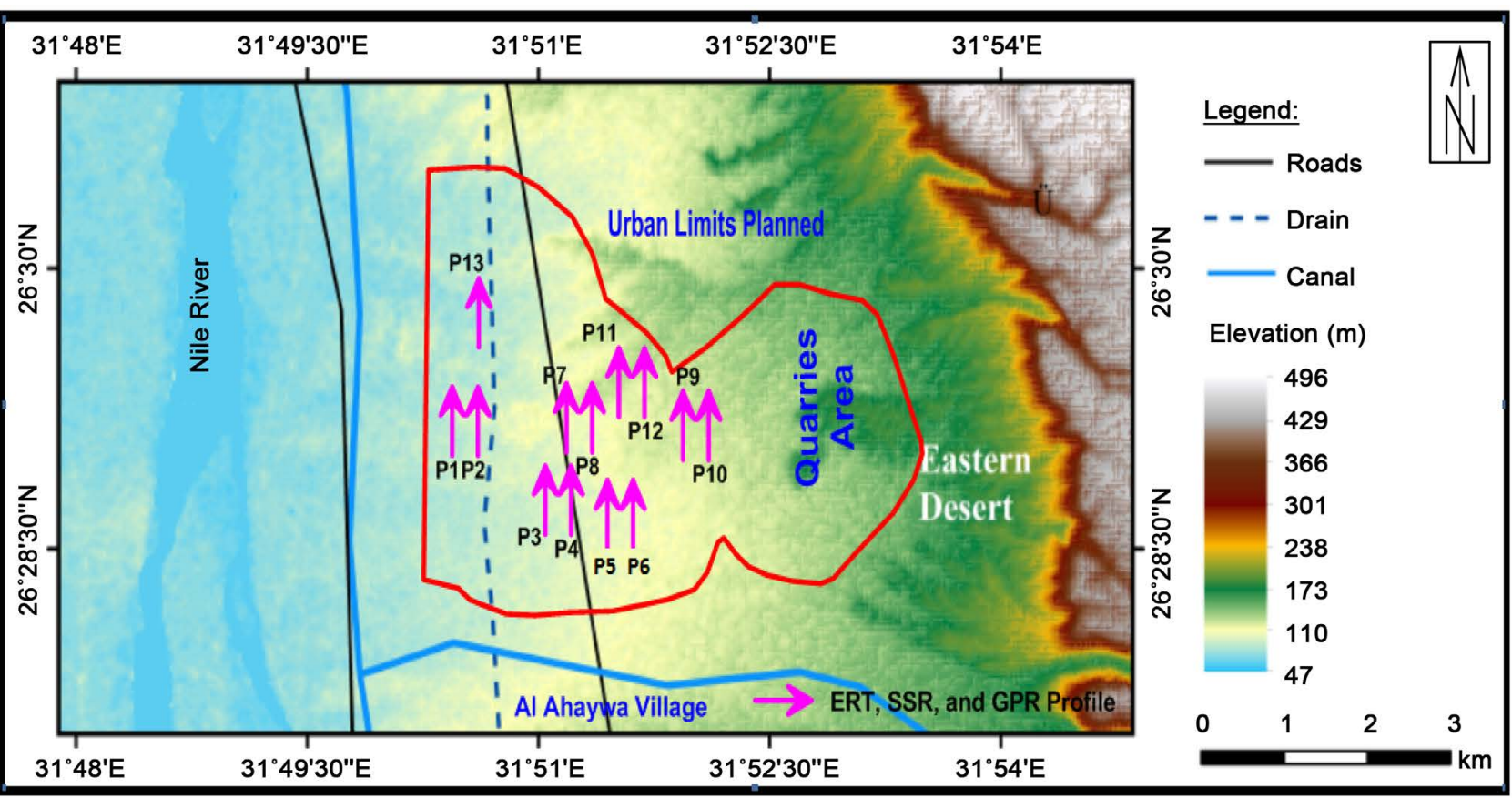

Figure 4. Location map of the New Sohag city shows the location of ERT, SSR and GPR profiles.

commonly applied to solve most of the engineering and environmental problems. A GPR system radiates short pulses of high-frequency EM energy into the ground from a transmitting antenna. The velocity of EM waves is related to the dielectric permittivity of subsurface materials. When this wave encounters the interface between two materials having different dielectric permittivity, a portion of the energy is reflected back to the surface, where it is detected by a receiver antenna and transmitted to a control unit for processing and display.

Depth of penetration of radar waves is a function of antenna frequency, dielectric constant and the electrical conductivity of the soils. However, low-frequency antennas achieve greater depth of penetration than those of high frequency, but they have poor spatial resolution. Conductive soils, such as clays, attenuate the radar waves much more rapidly than resistive soils such as dry sand and resistive rock [3].

A raw estimation of depth is obtained by multiplying the one-way travel time with the average propagation velocity of the GPR pulse inside the geological formation. The GPR method has been increasingly used for shallow subsurface mapping because of its capability to provide a high-resolution image of the near surface discontinuity and heterogeneity [22].

Thirteen GPR profiles have been acquired using RAMAC instrument with 100 $\mathrm{MHz}$ antenna; their lengths are $250 \mathrm{~m}$. The conducted GPR profiles is measured at the same location of the conducted (ERT) and (SSR) profiles as shown in Figure 4.

\section{Data Processing and Interpretation}

\subsection{Electrical Resistivity Tomography (ERT)}

The Conducted ERT data were processed using RES2DINV program package 
edited in 1998, [15] [16]. The measured data were plotted as "Apparent Resistivity Pseudo-sections" to check the data quality and measured point distribution. Applying "Least Square Approach" the measured apparent resistivity is inverted to true resistivity values in the form of modeled 2D Resistivity sections.

The ERT data were used to provide the distribution of electrical properties in the subsurface soil, to outline the high resistivity zones that could be attributed to the hard and dry calcareous sand, and to outline the low resistivity zones attributed to silty clay soil and water saturated soil.

The inspection of the conducted ERT profiles, two major geoelectric layers could classified as the following

- The top layer exhibits a moderate resistivity values ranging from $101 \mathrm{Ohm} \cdot \mathrm{m}$ to $410 \mathrm{Ohm} \cdot \mathrm{m}$ with average thickness of $5.0 \mathrm{~m}$ along all the conducted profiles. The ERT results correlation with the geologic information displays that this layer classified as gravel accumulation imbedded into the calcareous sandy layer.

- The bottom layer underlies the top layer which extended down to the end of the ERT sections is characterized by low resistivity values ranging from 15.7 $\mathrm{Ohm} \cdot \mathrm{m}$ to $39.8 \mathrm{Ohm} \cdot \mathrm{m}$ with thick thickness extends to the end of the profiles. This low resistivity value is due to the presence of silt/clay layer intercalation that extends with different lengths and thickness in all the surveyed profiles as shown in Figures 5-8.

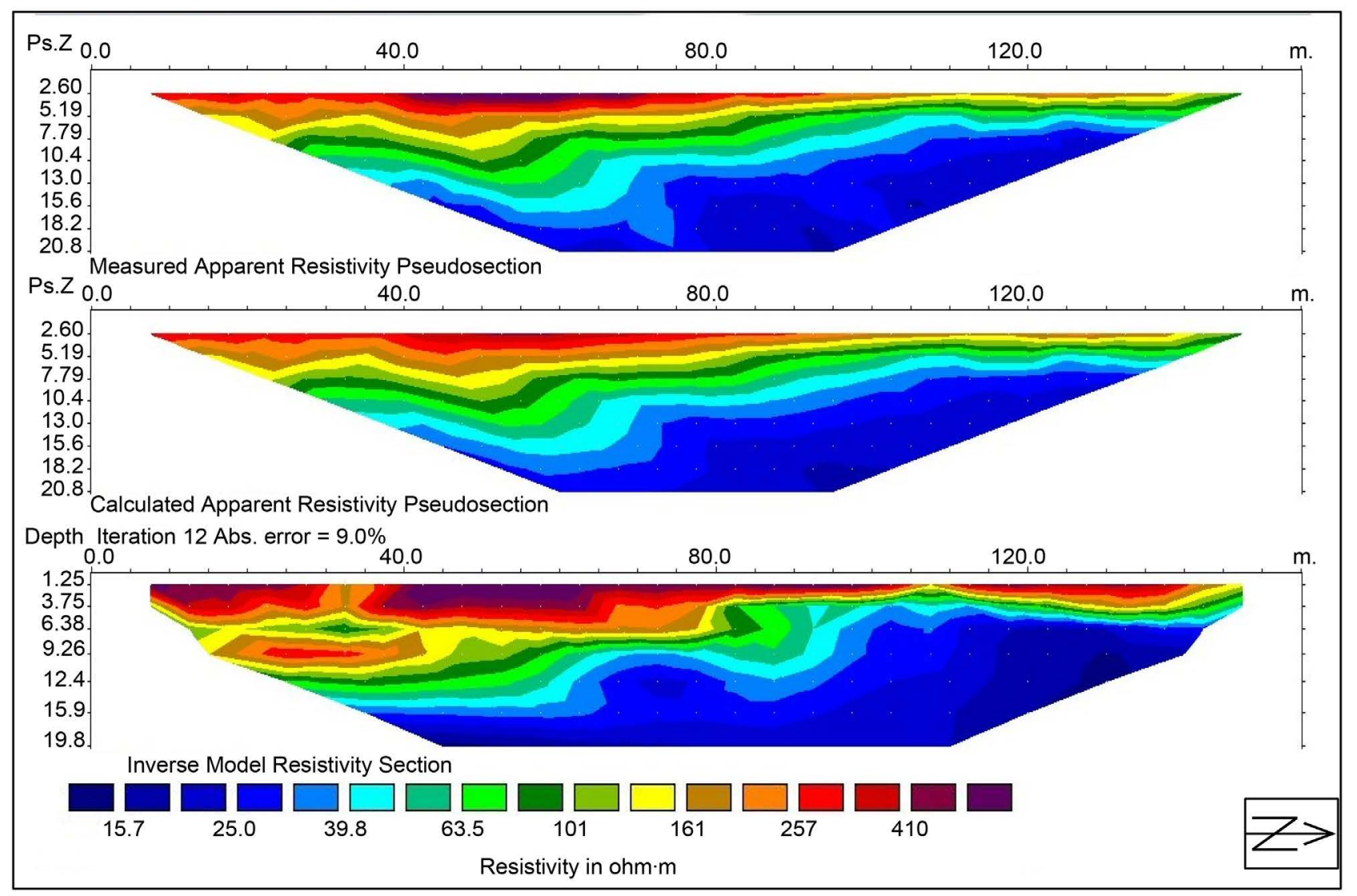

Figure 5. 2D Geoelectric cross section along profile No. 2. 


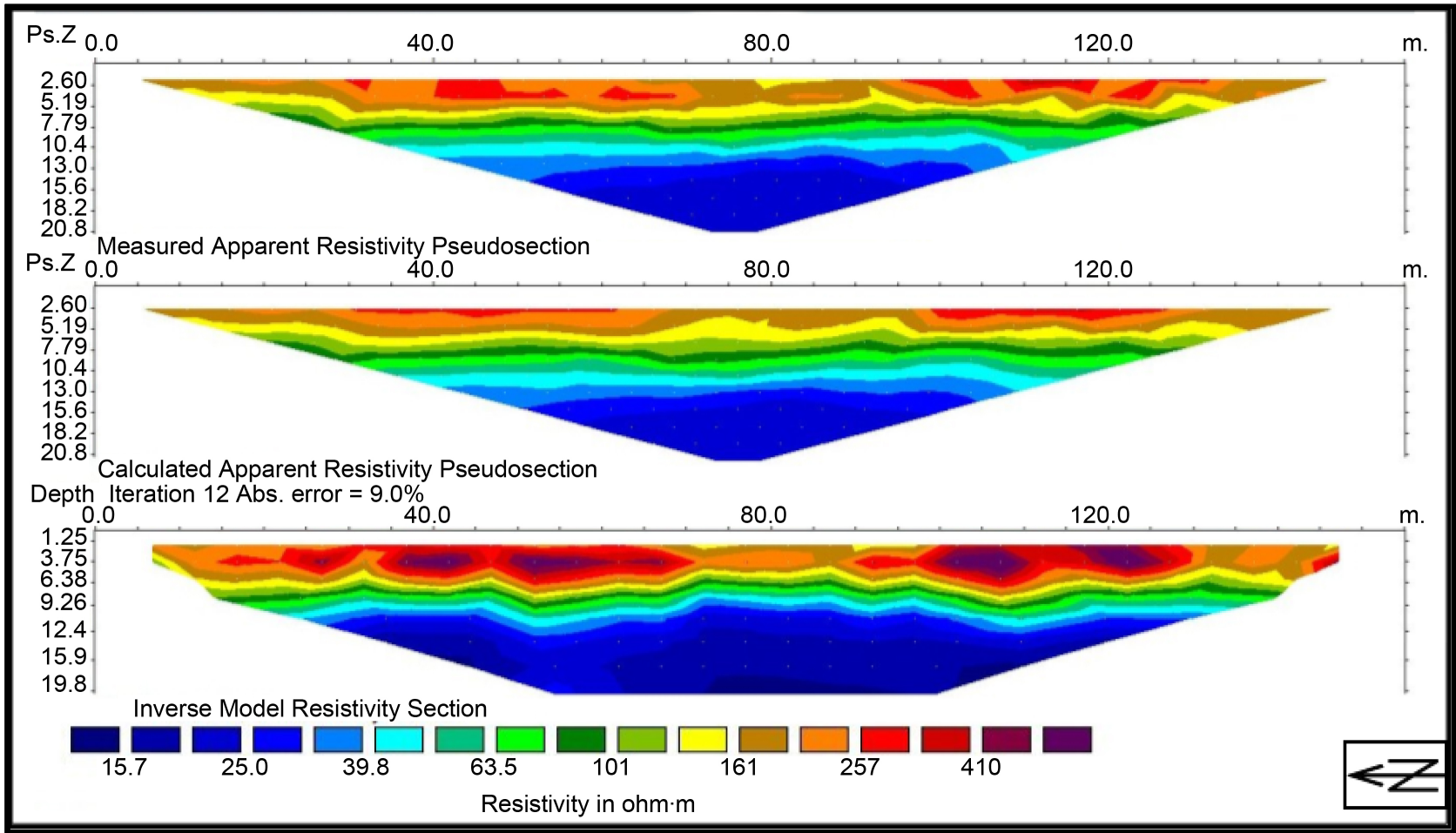

Figure 6. 2D Geoelectric cross section along profile No. 3.

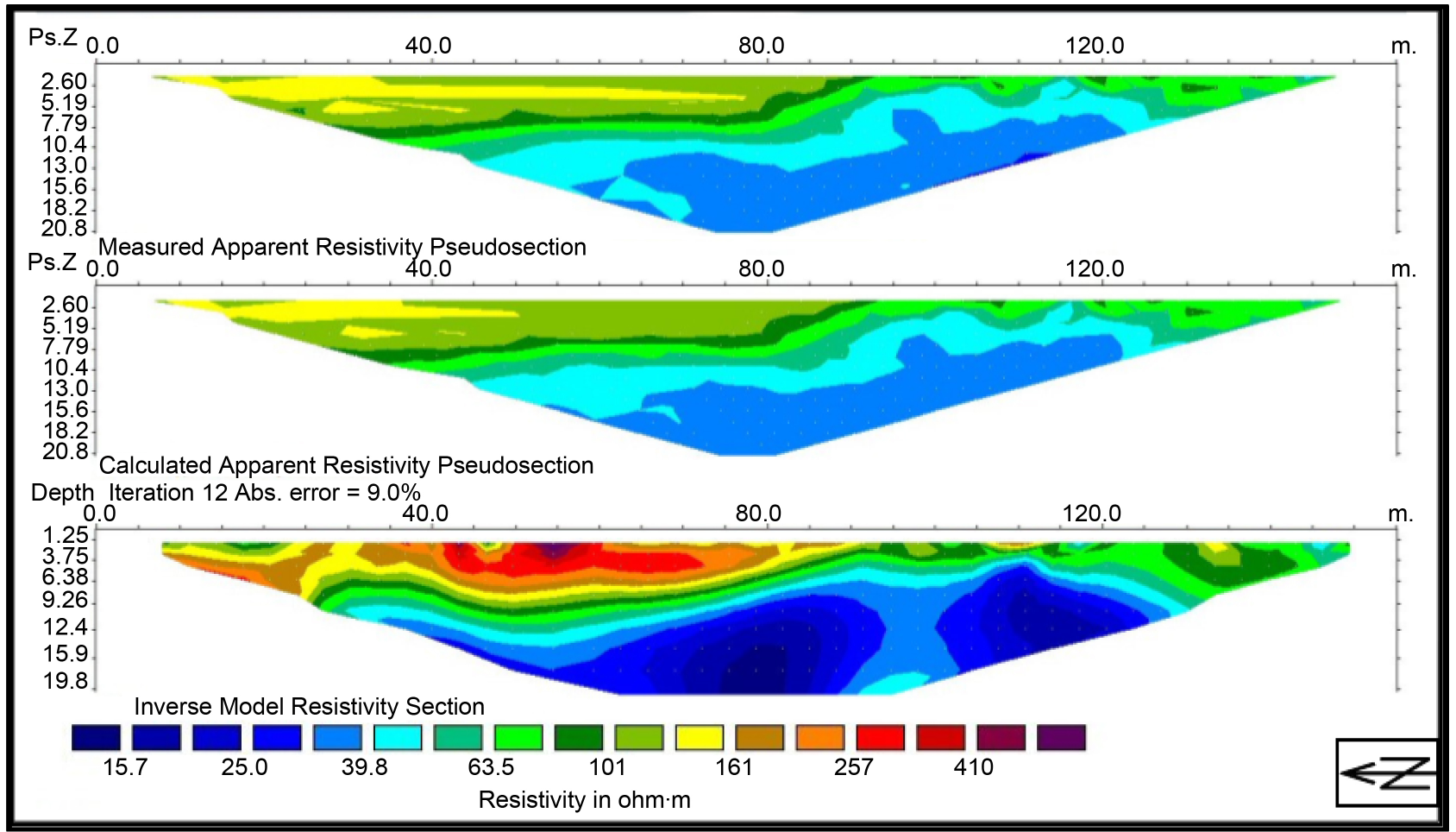

Figure 7. 2D Geoelectric cross section along profile No. 9.

\subsection{Shallow Seismic Refraction (SSR)}

The computer software (SEIS-REFA) program is used for estimating the parameters of the time-distance curve (X-T) curves and their corresponding depth- 


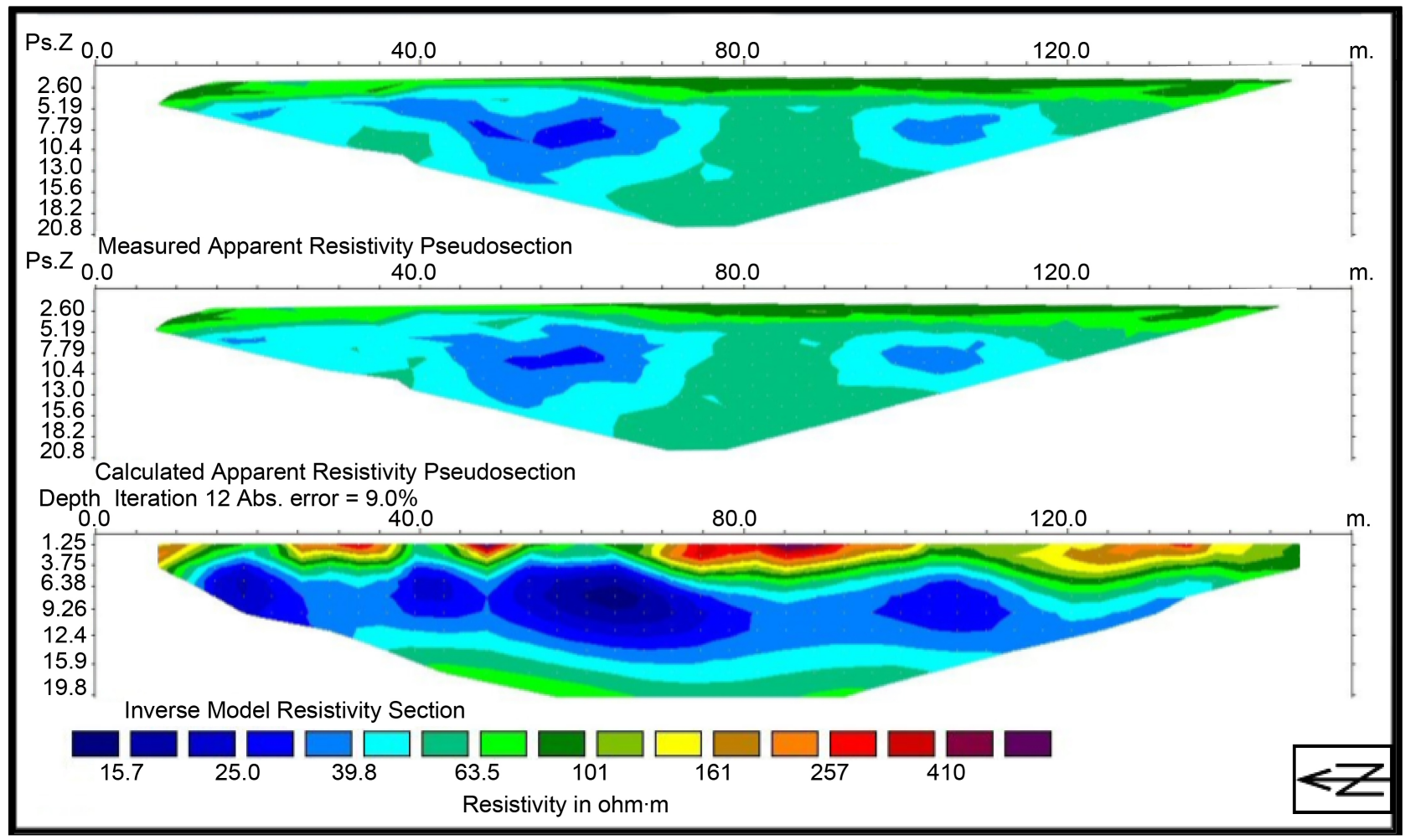

Figure 8. 2D Geoelectric cross section along profile No. 10.

velocity models. Figures 9-12 are showing example of travel time-distance curves and their depth-velocity models for the two conducted seismic profiles (P3 and P7) for (P-wave) and (SH-wave), respectively.

The Shallow seismic refraction (SSR) was applied to spectacle the areal distribution of the seismic velocities along the study area. The resultant seismic velocities will reflect the condition of solidity of the subsurface soil.

The inspection of the conducted seismic refracted profiles reveals the presence of two geoseismic layer according to their geoseismic velocities as follows:

- The first geoseismic layeris represented in the all conducted seismic Profiles as shown in Figures 9-12 with slightly variable thickness. It is characterized by $\mathrm{P}$-wave and $\mathrm{SH}$-wave velocities ranging from $800-1200 \mathrm{~m} / \mathrm{s}$, and $650-$ $900 \mathrm{~m} / \mathrm{s}$ respectively. This layer shows symmetrical thickness across the seismic profiles with an average thickness of $3 \mathrm{~m}$. This layer could be attributed to Calcareous sand (surface layer).

- The second geoseismic layer follows the surface layer with high seismic velocity for P-wave and SH-waveranges from $2000-2600 \mathrm{~m} / \mathrm{s}$, and $1800-2100$ $\mathrm{m} / \mathrm{s}$ respectively. This layer is extending till the end of the section. This layer is corresponding to hardsilty clay.

\subsection{GPR Data Interpretation}

The data are processed by using Reflex-win program, which operates under windows environment.

Only one reflector can be seen on the resulted GPR profiles. This reflector 


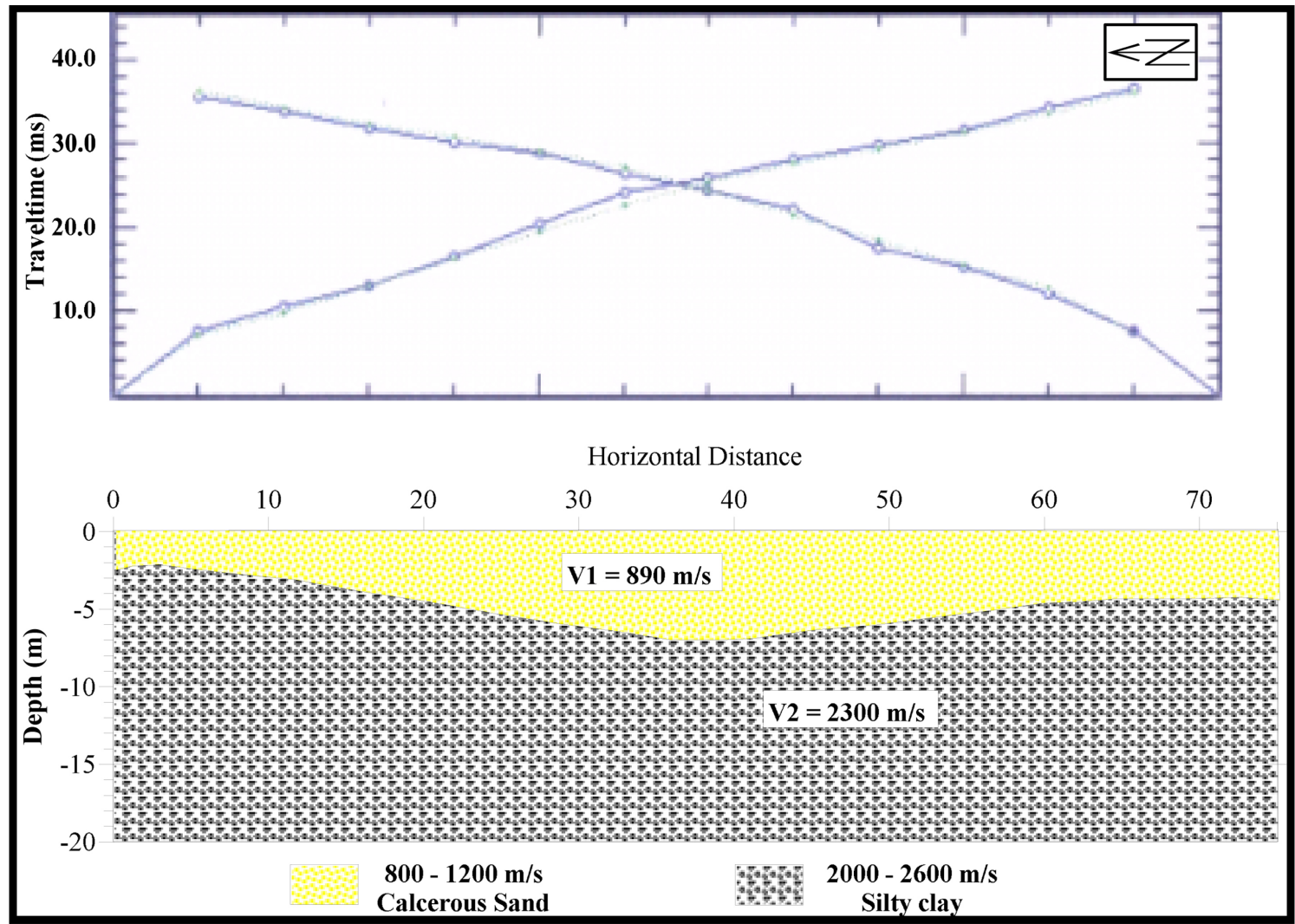

Figure 9. The lithological layers interpreted from the P-wave seismic refraction profile No. 3.

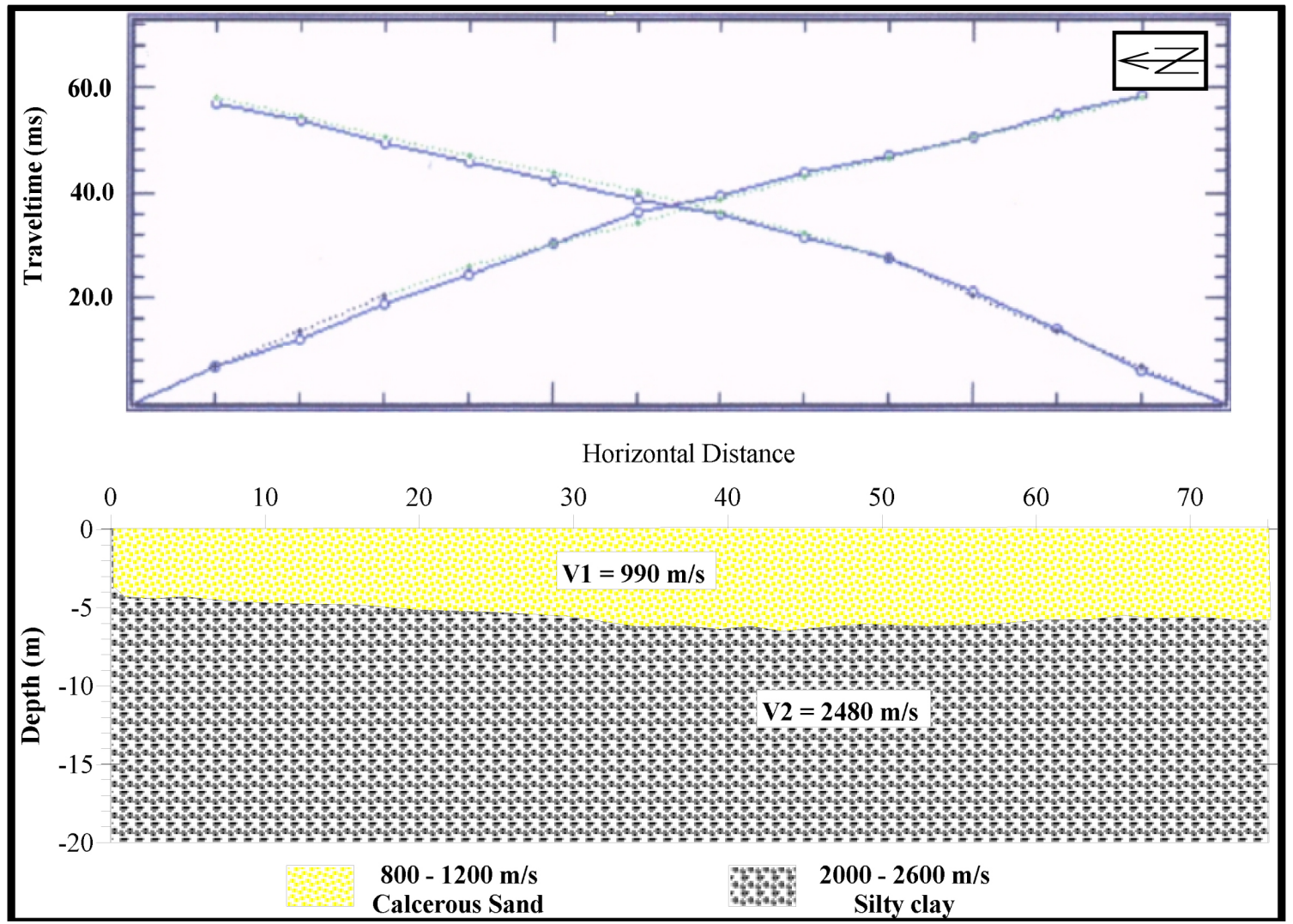

Figure 10. The lithological layers interpreted from the P-wave seismic refraction profile No. 7. 


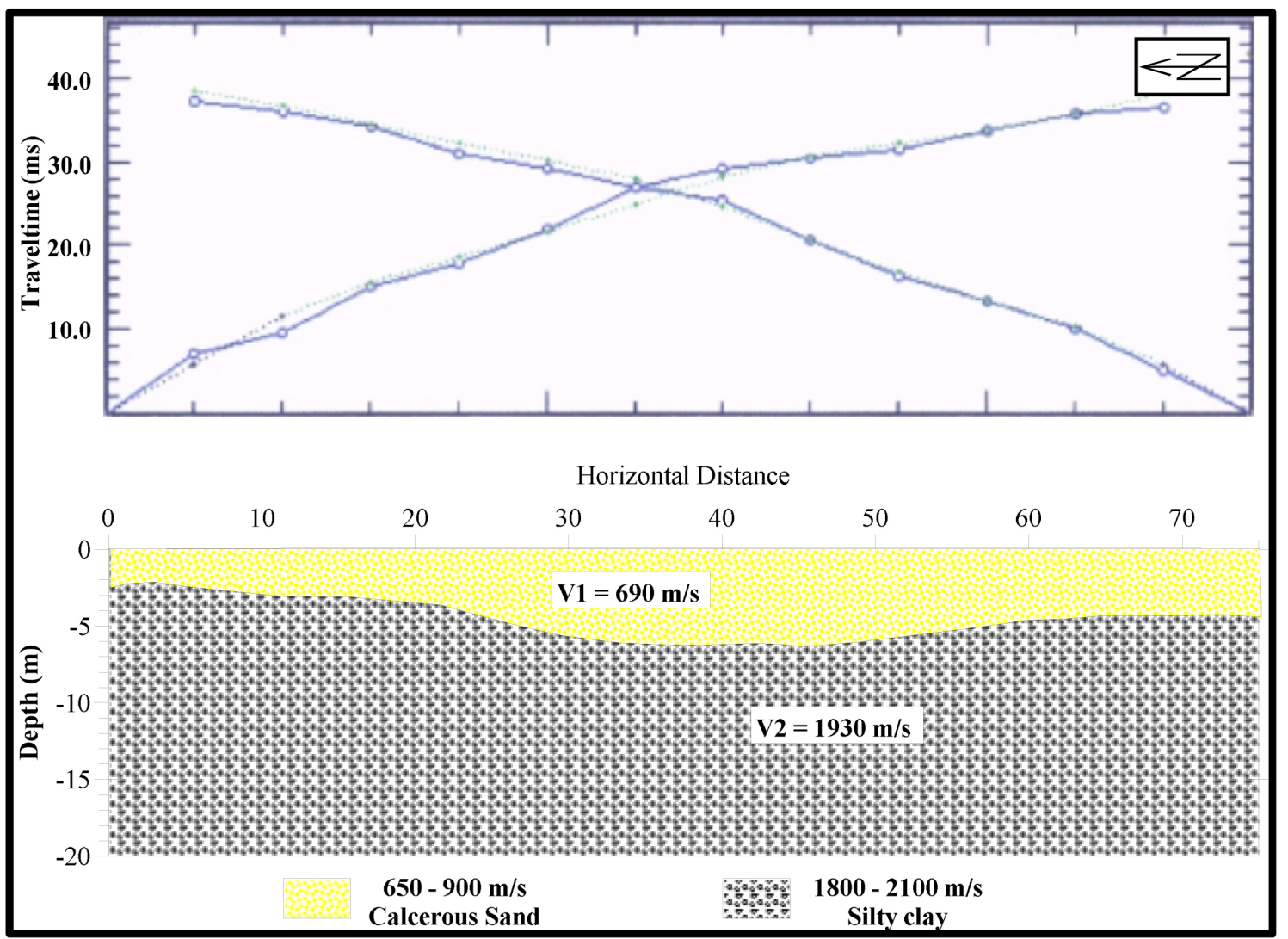

Figure 11. The lithological layers interpreted from the SH-wave seismic refraction profile No. 3.

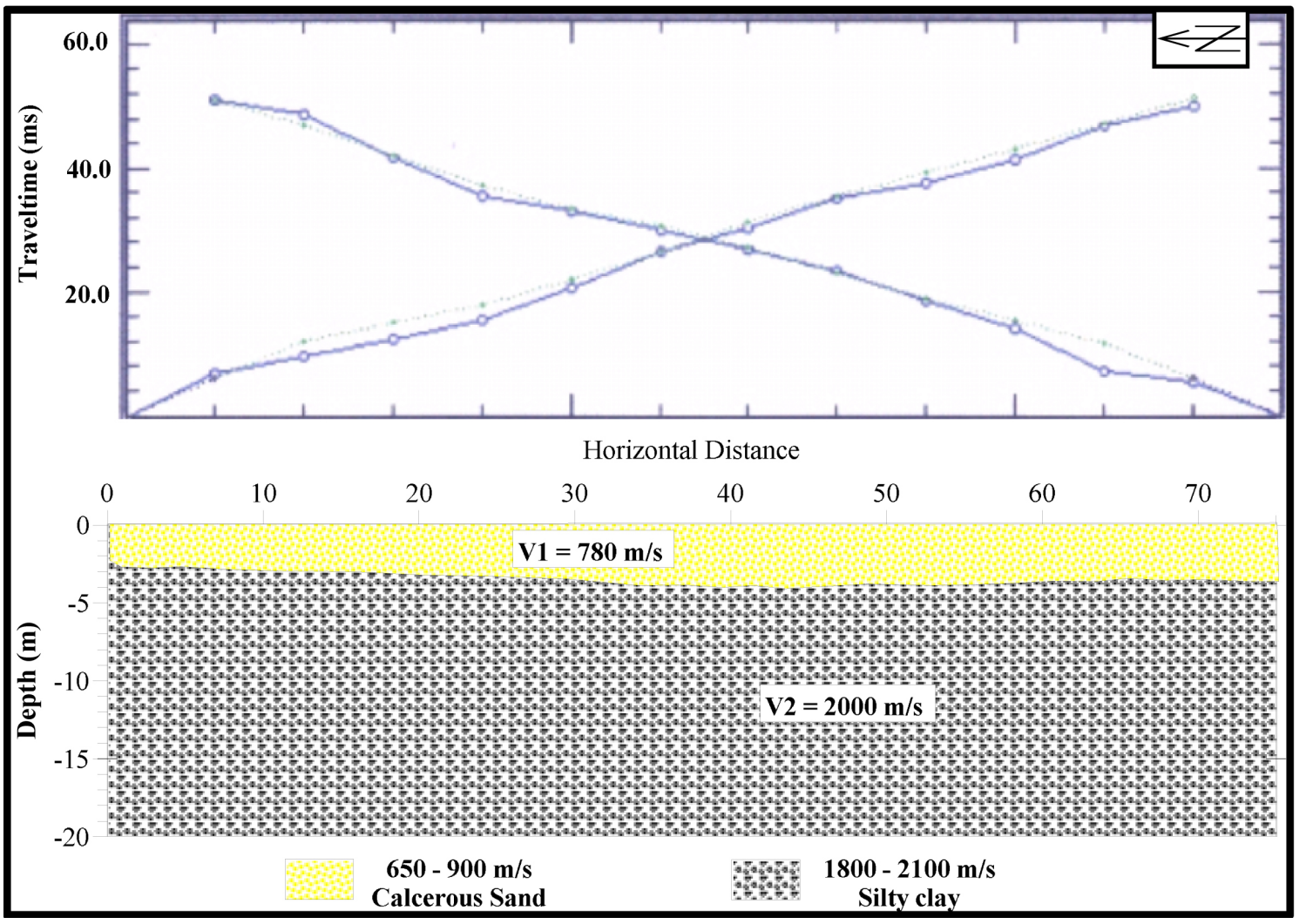

Figure 12. The lithological layers interpreted from the SH-wave seismic refraction profile No. 7. 
interpreted as the contact surface between the upper gravel and calcareous sand layer and the lower clay layer. The nature of the clay reflections changed from place to place in the study area, which can be interpreted as the presence of different type of clays, most probably due to difference in saturations. Figure 13 and Figure 14 are representing of geo-GPR cross section along Profiles No. (2 and 4).

The attenuation of the electromagnetic waves increases with material conductivity. Materials that have high attenuation include clays, silts, shales and seepage

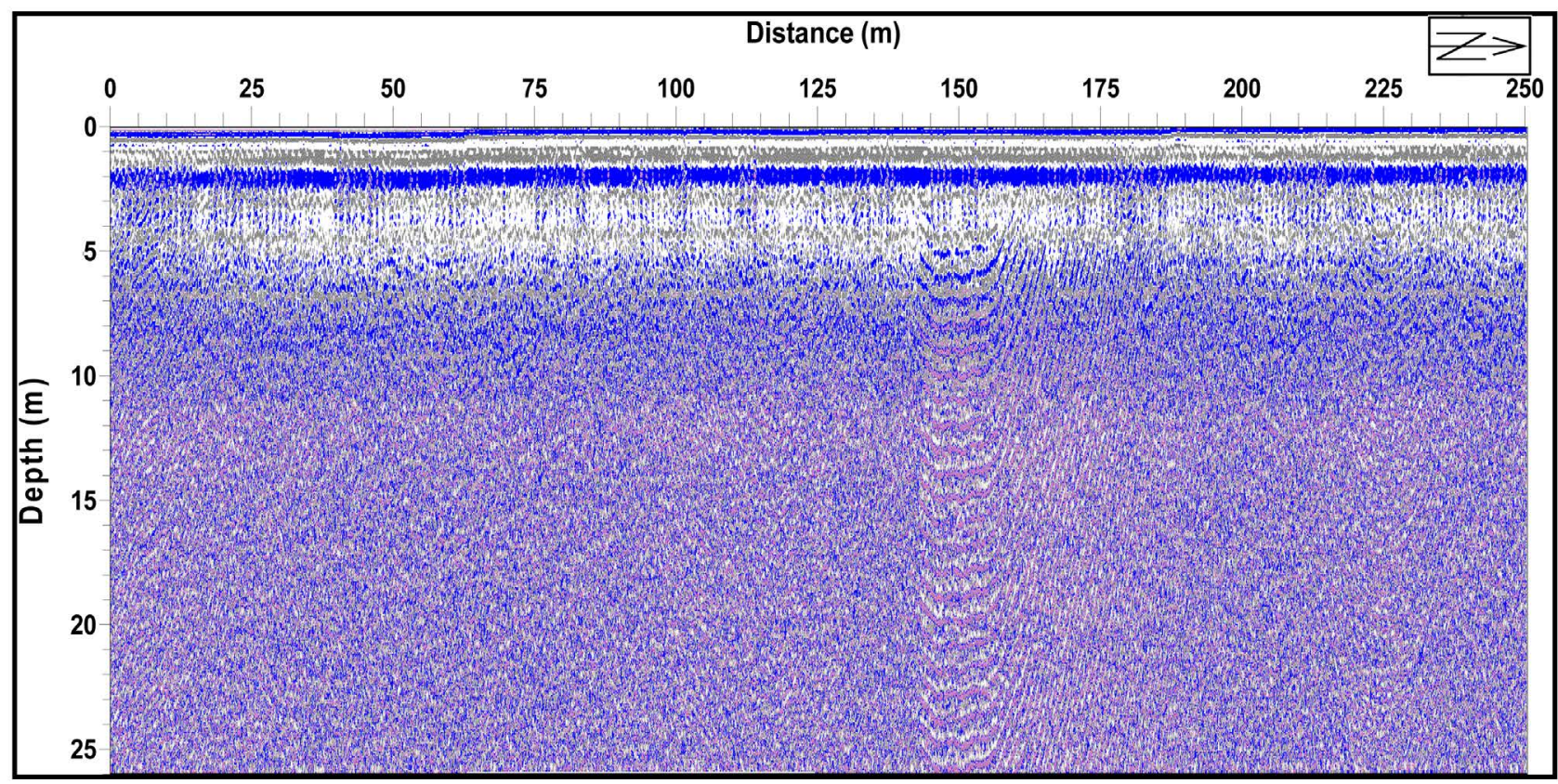

Figure 13. The Geo-GPR cross section along the Profile No. 2.

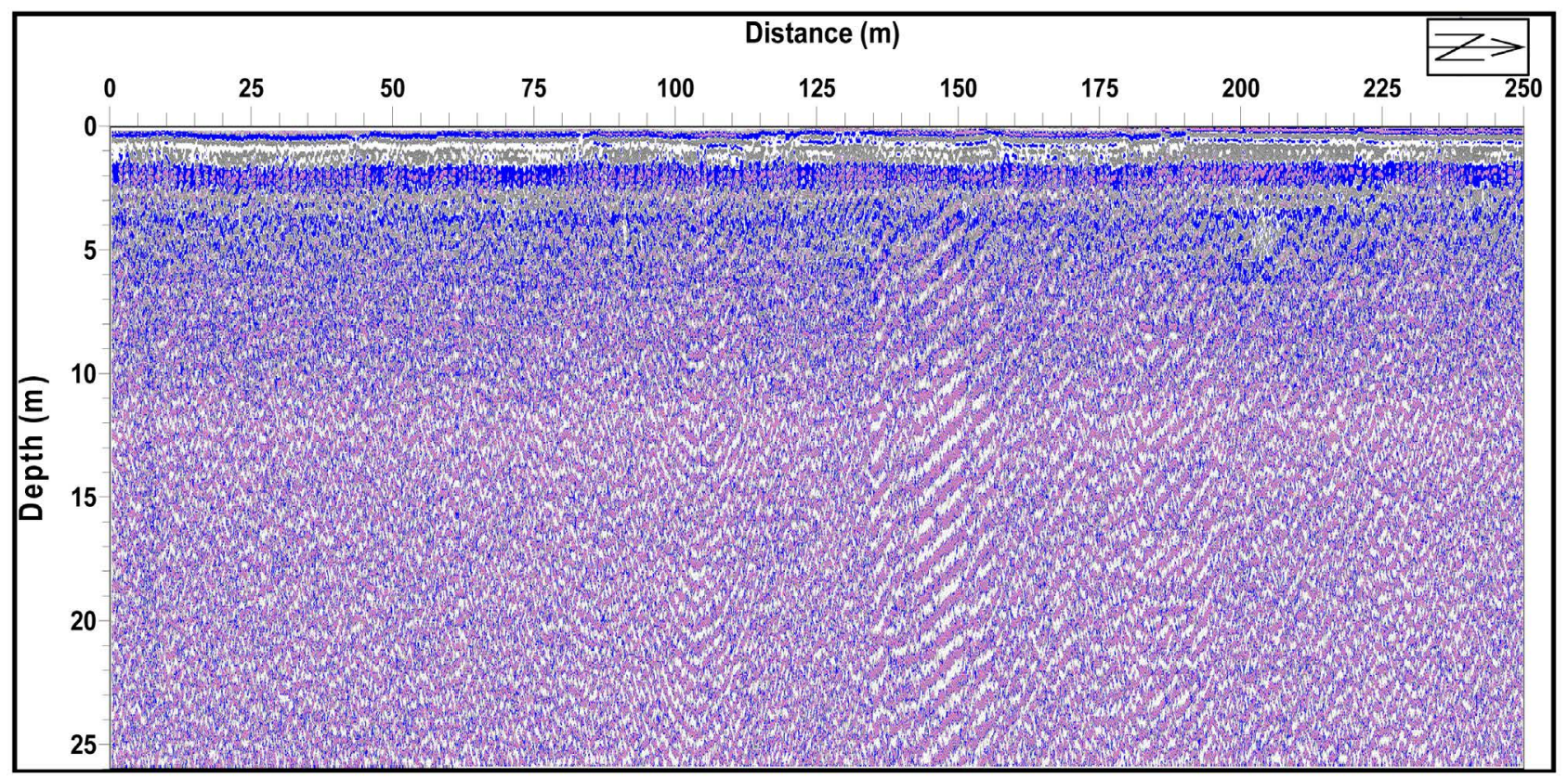

Figure 14. The Geo-GPR cross section along the Profile No. 4. 
water, while which have low attenuation include distilled water, air, dry sand and ice.

Electromagnetic waves penetrate to almost $5 \mathrm{~m}$ subsurface (surface layer) until reached to the clay layer that attenuating the waves and masking other layers underneath.

\section{Conclusions}

Electrical Resistivity Tomography (ERT), Shallow Seismic Refraction (SSR), and Ground Penetrating Radar (GPR) measurements were conducted over the same area at a new Sohag city (Akhmim Center), Egypt to image the shallow subsurface setting and locating any geological structures that may cause obstacles for the new community creations.

The ERT, SSR, and GPR data were collected along 13 parallel profiles distributed along the available places to investigate the shallow subsurface medium, identify the lithologic units and to outline the clayey zones that have a hazardous effect on the foundation and construction processes.

The interpretation of all the conducted geophysical methods exhibited that the reflector interpreted as the contact surface between the upper calcareous sand layer and the lower silty clay layer. This reflector is well identified from the conducted three tools.

The lower clayey layer that highly identified by its high conductivity from ERT measurements and its highly ability of attenuating the electromagnetic waves from GPR measurements, should be taken into consideration when planning and designing the new Sohag city.

The integrated results obtained from the interpretation of the ERT, the SSR and the GPR records conducted over the study area classified lithologically into calcareous sandy, hardsilty clay layers. These layers are identically consistence with the typical lithological section of Akhmim Center [8] as shown in Figure 3.

\section{Recommendation}

The hazardous effect of the delineated clayey formations can be generated in case of water leakage, which may come from surface irrigation and/or defect in sanitary systems. The nature of the clayey layer is changed from place to place in the study area, which can be interpreted as the presence of different types of clays, most probably due to the difference in degree of saturations.

\section{References}

[1] Bishay, Y. (1961) Biostratigraphic Study of the Eocene in the Eastern Desert between Samalut and Assiut by the Large Foraminifera. S N Publisher, Delhi, 7.

[2] Bishay, Y. (1966) Studies on the Large Foraminifera of the Eocene (The Nile Valley between Assiut and Cairo and SW Sinai). PhD Thesis, Alexandria University, Alexandria.

[3] Davis, J.L. and Annan, A.P. (1989) Ground Penetrating Radar for High Resolution Mapping of Soil and Rock Stratigraphy. Geophysical Prospecting, 37, 531-551. https://doi.org/10.1111/j.1365-2478.1989.tb02221.x 
[4] Dobrin, M.B. (1976) Introduction to Geophysical Prospecting. 3rd Edition, McGraw Hill, New York, 25-56, 292-336, 568-620.

[5] Dutta, N.P. (1984) Seismic Refraction Method to Study the Foundation Rock of a Dam. Geophysical Prospecting, 32, 1103-1110. https://doi.org/10.1111/j.1365-2478.1984.tb00757.x

[6] Egyptian Geological Survey and Mining Authority (EGSMA) (1989) Geological Map of Upper Egypt.

[7] El Naggar, Z. (1970) Litho Stratigraphic Subdivision for the Late Cretaceous-Early Paleogene Succession in the Nile Valley. Paper 64(B-3).

[8] General Authority for Educational Buildings (2003) The Geotechnical Encyclopedia for Egypt, The General Geotechnical, Topographical, Geomorphological, Geological and Hydrogeological Properties for Egypt. General Authority for Educational Buildings.

[9] Griffiths, D.H. and Barker, R.D. (1993) Two-Dimensional Resistivity Imaging and Modeling in Areas of Complex Geology. Journal of Applied Geophysics, 29, 224226.

[10] Hermina, M. (1989) The Surrounding of Kharga, Dakhla and Farafra Oasis. In: Said, Ed., The Geology of Egypt, Balkena, Rotterdam, 259-292.

[11] Issawi, B. (1968) The Geology of Kukur-Dungul Area. Paper No. 46, Geological Survey, Cairo.

[12] Issawi, B. (1972) Review of Upper Cretaceous-Lower Tertiary Stratigraphy in Central and Southern Egypt. The American Association of Petroleum Geologists Bulletin, 56, 1448-1463.

[13] Issawi, B., Hassan, M.W. and Osman, R. (1978) Geological Studies in the Area of Kom Ombo, Eastern Desert, Egypt. AGSE, 8, 187-235.

[14] Issawi, B. and McCauley, J.F. (1992) The Cenozoic Rivers of Egypt: The Nile Problem. In: Freidman, R. and Adams, B., Eds., The Followers of Horus, Oxford Press, Oxford, 121-138.

[15] Loke, M.H. (2000) Time-Lapse Resistivity Imaging Inversion. Proceedings of the 5 th Meeting of the Environmental and Engineering.

[16] Loke, M.H. (2002) 2-D and 3-D Electrical Imaging Surveys. www.geoelectrical.com

[17] Mansour, H., Philobbos, E., Mohamed, H. and Ahmed, S. (1982) Contribution to the Geology of the Area West and Southwest of Sohag. Bulletin of Faculty of Science Assiut University, 2, 304-334.

[18] Omara, S., El-Tahlawi, M. and Hafez, H. (1970) The Geology of the Environments of Assiut. Bulletin of Society of Geography, 43.

[19] Omer, A.A. (1996) Geological, Mineralogical and Geochemical Studies on the Neogene and Quaternary Nile Basin Deposits, Qena-Assiut Stretch, Egypt. PhD Thesis, Geology Department of Faculty of Science, South Valley University, Sohag.

[20] Omer, A.A. and Issawi, B. (1998) Litho Stratigraphical, Mineralogical and Geochemical Studies on the Neogene and Quaternary Nile Basin Deposits, Qena-Assiut Stretch, Egypt. The 4th International Conference on Geology of the Arab World, Cairo.

[21] Paulissen, M. and Vermeersch, P.M. (1987) Earth, Man and Climate in the Egyptian Nile Valley during the Pleistocene. In: Close, A., Ed., Prehistory of North Africa, Southern Methodist University Press, Dallas, 29-67.

[22] Reynolds, J.M. (1997) An Introduction to Applied Environmental Geophysics. John Wiley \& Sons Ltd., West Sussex. 
[23] Said, R. (1960) Planktonic Foraminifera from the Thebes Formation, Luxor, Egypt. Micropaleontology, 16, 227-286. https://doi.org/10.2307/1484234

[24] Said, R. (1961) Tectonic Framework of Egypt and Its Influence on Distribution of Foraminifera. Bulletin of the American Association of Petroleum Geologists, 45, 198-218.

[25] Said, R. (1962) The Geology of Egypt. Elsevier, Amsterdam.

[26] Said, R. (1971) Explanatory Notes to Accompany the Geological Map of Egypt. Egyptian Geological Survey, 3, 89-105.

[27] Said, R. (1975) Some Observations on the Geomorphology of the South Western Desert of Egypt and Its Relation to the Origin of Groundwater. Annales of the Geological Survey of Egypt, 5, 61-70.

[28] Said, R. (1981) The Geological Evaluation of the River Nile. Springer Verlag, New York, Heidelberg, Berlin. https://doi.org/10.1007/978-1-4612-5841-4

[29] Said, R. (1983) Proposed Classification of the Quaternary of Egypt. Journal of African Earth Sciences, 1, 41-45.

[30] Said, R. (1990) Geology of Egypt. A.A. Balkema, Rotterdam.

[31] Sharma, P.V. (1974) Geophysical Methods in Geology. Elsevier, New York.

[32] Sheleby, A., Said, M. and Eid, M. (2000) Paleogene Lithostatigraphy of the Area West of the Nile Valley between Qena and South Assiut. Annual of Geological Survey of Egypt, 23, 563-578.

[33] Wendorf, F. and Said, R. (1967) Paleolithic Remains in Upper Egypt. Nature, 215, 244-247. https://doi.org/10.1038/215244a0

[34] Wendorf, F. and Schild, R. (1976) Pre-History of the Nile Valley. Academic Press, Cambridge.

Submit or recommend next manuscript to SCIRP and we will provide best service for you:

Accepting pre-submission inquiries through Email, Facebook, LinkedIn, Twitter, etc. A wide selection of journals (inclusive of 9 subjects, more than 200 journals)

Providing 24-hour high-quality service

User-friendly online submission system

Fair and swift peer-review system

Efficient typesetting and proofreading procedure

Display of the result of downloads and visits, as well as the number of cited articles

Maximum dissemination of your research work

Submit your manuscript at: http://papersubmission.scirp.org/

Or contact ijg@scirp.org 